\title{
E-Partography- A Rural Tertiary Hospital Experience
}

\section{Pramod Kumar ${ }^{1 *}$, Poonam Varma Shivkumar ${ }^{1}$, Madhukar Barambhe ${ }^{2}$, Megha Bathla ${ }^{1}$, Jennifer lowe ${ }^{3}$, Taizoon Khokhar ${ }^{3}$, Samita Bharadwaj ${ }^{3}$, Vinay Jain ${ }^{3}$}

${ }^{1}$ Department of Obstetrics and Gynaecology, Mahatma Gandhi Institute of Medical Sciences, Maharashtra, India ${ }^{2}$ Department of Community Medicine, Mahatma Gandhi Institute of Medical Sciences, Maharashtra, India ${ }^{3}$ Jivdaya health foundation, Texas, USA

"Corresponding Author: Pramod Kumar, Department of Obstetrics and Gynaecology, Mahatma Gandhi Institute of Medical Sciences, Maharashtra, India, E-mail: pramodkumar@mgims.ac.in

Received: 29 September 2019; Accepted: 11 October 2019; Published: 25 October 2019

Citation: Pramod Kumar, Poonam Varma Shivkumar, Madhukar Barambhe, Megha Bathla, Jennifer lowe, Taizoon Khokhar, Samita Bharadwaj, Vinay Jain. E-photography- A Rural Tertiary Hospital Experience. Obstetrics and Gynecology Research 2 (2019): 072-079.

Keywords: Pregnant Women; Malaria; Interventions

\section{Introduction}

A partogram or partograph is a composite graphical record of mother and foetus during labour which is entered on paper with respect to time. The parameters entered includes fetal heart rate, cervical dilatation, duration of labour, uterine contractions and vital signs of mother. This one sheet of paper actually provides an accurate record of the progress in labour. By viewing this partograph, any delay or deviation from normal can be detected immediately and treated accordingly.

The advantage of the partograph are enormous and include

- Provides information on single sheet of paper at a glance
- No need to record labour events repeatedly

- Provides a practical teaching aid

- Is an efficient means of exchange of technical information about labour progress between teams of caregivers.

- Prediction of deviation from normal progress of labour

- Reduces pregnancy complication rates

- Improvement in maternal morbidity, perinatal morbidity and mortality 1

The commonest partograph which is used globally is MODIFIED WHO PARTOGRAPH [1]. This partograph has been time tested and can be easily understood by auxillary nurse midwives and nurses too. The Modified WHO partograph is as following - 


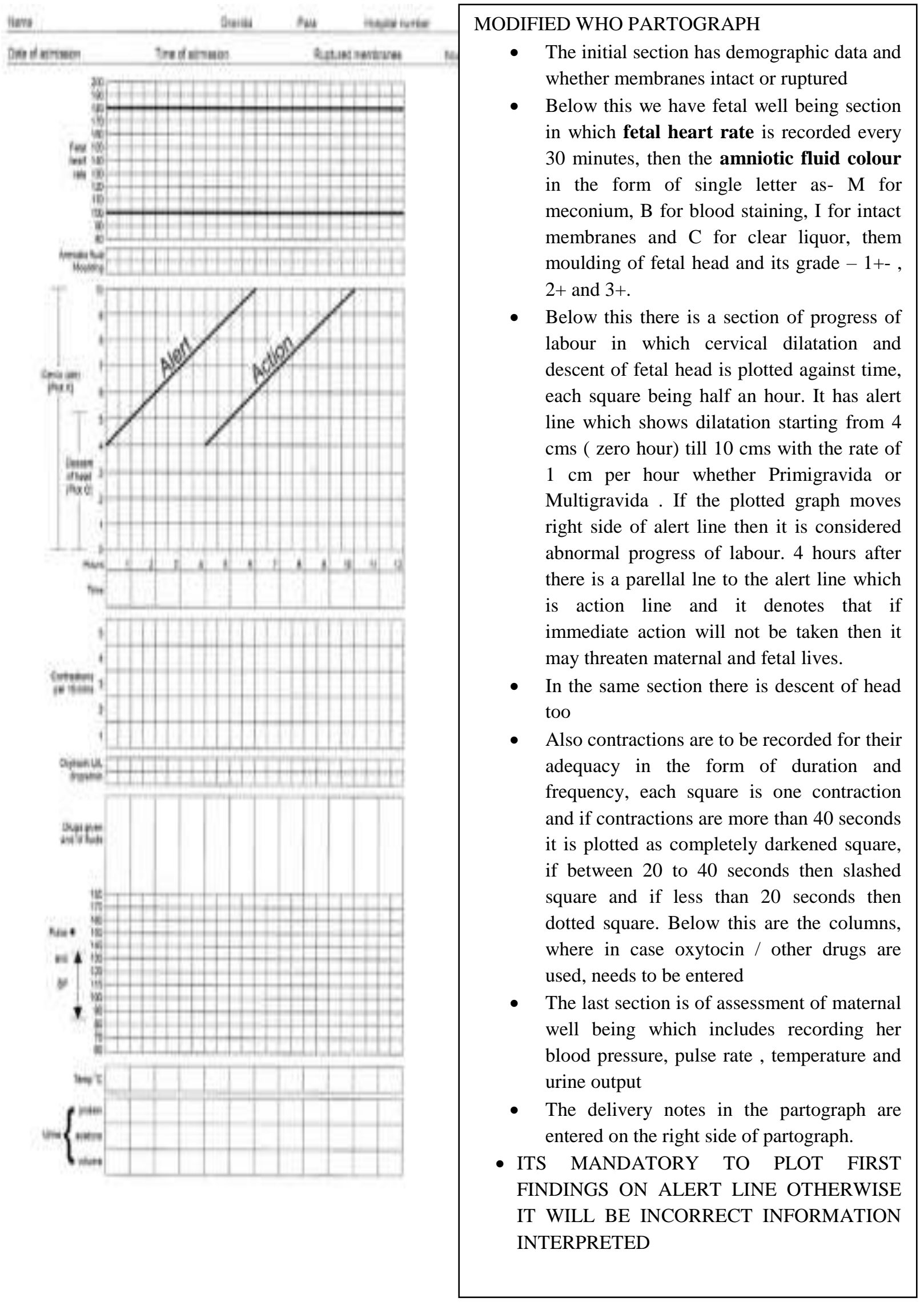


World Health Organisation model has been used for many years in the peripheral maternity clinics of Pikine, Senegal, to monitor labour. 1022 pregnant women were monitored by partogram during 4 months. The alert line was crossed in $100(9.8 \%)$ of these cases and the frequency of neonatal resuscitation was higher for this group (relative risk 4.0, 95\% confidence interval 2.37.1 ; p less than 0.0001), as was the number of "fresh" stillbirths (5.3, 1.8-15.6; p less than 0.01) (recent death may have occurred during labour). Among the women who crossed the alert but not the action line, neonatal resuscitation was also four times more likely than for the normal labour group $(4.0,2.1-7.6$; $\mathrm{p}$ less than 0.001 ), and the fresh stillbirth rate was higher but not significantly so. For women who crossed both lines, the fresh stillbirth rate was ten times higher than for women in the normal labour group $(9.9,2.8-34.7$; p less than 0.001 ). Crossing the alert line had a sensitivity of $27 \%$, a specificity of $93 \%$, and a positive predictive value of $17 \%$ for neonatal resuscitation. If the action line was chosen as the decision level, the positive predictive value remained the same but the sensitivity was only 8 [3].

The problem with paper partography is that it needs training of users, it has to be plotted and interpreted correctly. Number of times, in busy labour rooms it is not plotted prospectively rather plotted after delivery retrospectively and attached in the case sheets. Most of these partographs are incomplete and most of the time they are not even looked at, so there was a desperate need of a mechanism by which this important paper sheet can be utilized conveniently and adequately, the E - Partography has come up as a promising device. E partogram is a modern tool for computerized recording of labour data which is called as an electronic partogram . Electronic documentation brings along a number of benefits:

- Instant access to patient records
- Sharing information with patients and doctors

- More effective diagnostics and potential reduction of medical errors

- Interconnection of data and systems as well as the possibility of subsequent data analysis and evaluation in a variety of applications working with big data. One of such applications in real life is a decision support such as case-based reasoning (CBR).

- Prospective recording of data and detection if retrospective completion of partogram as it is real time data capture.

- It also captures whether the monitoring of labouring women is adequate or not.

- As the same data is shared to the unit incharges sitting anywhere in their connected devices, they can monitor their patients and can communicate if any deviation seen.

- This record is in real time, so medico legally it helps and prevents any change in the documents.

\subsection{Title}

Ensuring the complete and accurate plotting of ELECTRONIC MODIFIED WHO PARTOGRAPH in all eligible laboring women ( $100 \%$ ) and assessing the reduction in existing maternal as well as fetal labor complication rates at a rural tertiary care centre

\subsection{Aims and objectives}

The overall aim was to reduce maternal as well as fetal complications during labor by complete plotting of electronic modified WHO partograph.

Objectives were -

1. $100 \%$ use of accurate electronic partography in both low as well as high risk eligible laboring women and ensuring that they are correctly plotted. 
2. Utility of electronic partograph in identifying maternal complications such as prolonged labor due to abnormal uterine contraction, abnormal descent \& abnormal cervical dilatation, obstructed labor, others

3. Comparing the electronic partograph utility in low as well as high risk groups

4. 4.Utility of electronic partograph in reducing the fetal complications such as fetal distress and intrapartum still births

5. 5.Comparing the fetal complications in low as well as high risk groups

\section{Material and Method}

The study was conducted over two and a half years at MGIMS, Sevagram, Wardha, Maharashtra, India funded by "Jiv Daya Foundation- Maternal Health Project in collaboration with Jiv Daya foundation, Dallas, USA. All parturient were included who reported to the labor room. It was a descriptive study based on a prospective document review which will be the modified WHO partographs having complete information and findings of the $100 \%$ of eligible laboring women and also their materno-foetal outcome.

\subsection{Inclusion And exclusion criteria}

This study included all the modified WHO partographs of the women except of those who were admitted in the second stage of labor. In addition to women already in prolonged labor, severe oligohydramnios where intervention was been planned, intrauterine foetal death (IUFD), previous caesarean section plus breech presentation, pregnancy with human immunodeficiency virus (HIV) infection, and elective caesarean section was excluded because the partograph completion is not recommended for mothers with above mentioned characteristics.

\subsection{Sample size}

The sample size in the present study was be determined by ensuring $100 \%$ partography for laboring women after all exclusion criteria. Expected size was around 3000 to 3100 annually. The total period of recording was one and a half year with 6 months for data analysis, report formation and policy making. A pre-tested and structured checklist were developed to ensure accurate filling of all the variables included as components of the modified WHO partograph. In order to produce a more objective assessment, the parameters of labor /part of the modified WHO partograph were assessed to determine whether they will have been monitored according to standard protocol [4].

Standard protocols are well defined based on the time interval as follows :

a. Cervical dilatation, moulding, descent of the presenting part and blood pressure monitored every four hours.

b. Fetal heart rate, maternal pulse and uterine contractions monitored every 30 minutes.

c. Condition of the baby after birth should always be recorded on the partograph in the appropriate section of the partograph to include the Apgar score of $\geq 7$ will be considered satisfactory in this study [6].

Our goal was to maintain $100 \%$ standard protocol. There were written guidelines and trained personnel in the existing labour room staff on how to complete the partograph for recording and management of labor in the labor room. A team of data collectors including one of the principle investigator or co-investigator had systematically reviewed all the partographs and documented the required information using the checklist. All partographs were scrutinized for documentation of cervical dilatation, uterine contraction, foetal heart rate, action line crossed/ not 
crossed, maternal B.P., moulding, descent of the presenting part, state of membranes and condition of the baby after birth.
3. Results

The observation of the study conducted from $16 / 11 / 2013$ to $07 / 06 / 2016$ and following results were observed -

\begin{tabular}{|l|l|l|l|l|}
\hline $\begin{array}{l}\text { TOTAL } \\
\mathbf{9 9 7 9}(\mathbf{1 0 0 \%})\end{array}$ & $\begin{array}{l}\text { ELIGIBLE } \\
\mathbf{5 6 3 7}(\mathbf{5 6 . 4 9 \%})\end{array}$ & $\begin{array}{l}\text { NON ELIGIBLE } \\
\mathbf{4 3 4 2}(\mathbf{4 3 . 5 1 \% )})\end{array}$ \\
\hline \multirow{3}{*}{} & LOW RISK & HIGH RISK & FULLY DILATED & OTHERS \\
\cline { 2 - 5 } & NO & NO & NO & NO \\
& $\%$ & $\%$ & $\%$ & $\%$ \\
\cline { 2 - 5 } & 4260 & 1377 & 1978 & 2364 \\
& 75.58 & 24.42 & 45.45 & 54.55 \\
\hline
\end{tabular}

Table 1: Total women attended labor room.

\begin{tabular}{|c|c|c|c|c|}
\hline \multirow{7}{*}{$\begin{array}{l}\text { TOTAL } \\
\text { ELIGIBLE } \\
\text { WOMEN } \\
5367(100 \%)\end{array}$} & \multicolumn{4}{|c|}{ SOCIOECONOMIC STATUS } \\
\hline & \multirow{2}{*}{\begin{tabular}{|ll} 
LOW & INCOME \\
GROUP & \\
\end{tabular}} & LOW RISK & $2387(74.35 \%)$ & \multirow{2}{*}{$\begin{array}{l}\text { MAX LOW } \\
\text { INCOME GROUP }\end{array}$} \\
\hline & & HIGH RISK & $824(25.64 \%)$ & \\
\hline & \multirow{2}{*}{$\begin{array}{l}\text { MIDDLE INCOME } \\
\text { GROUP }\end{array}$} & LOW RISK & $1237(78.24 \%)$ & \multirow[t]{2}{*}{ HIGH RISK CASES } \\
\hline & & HIGH RISK & $344(21.75 \%)$ & \\
\hline & \multirow{2}{*}{$\begin{array}{ll}\text { HIGH } & \text { INCOME } \\
\text { GROUP } & \end{array}$} & LOW RISK & $636(75.30 \%)$ & \multirow[t]{2}{*}{ IN ALL GROUPS } \\
\hline & & HIGH RISK & $209(24.70 \%)$ & \\
\hline
\end{tabular}

Table 2: Socioeconomic status.

\begin{tabular}{|c|c|c|c|c|}
\hline $\begin{array}{l}\text { LOCALITY } \\
\text { Total } 5637(100 \%)\end{array}$ & RISK GROUP & PARITY & $\begin{array}{l}\text { LOW RISK } \\
4230\end{array}$ & $\begin{array}{l}\text { HIGH RISK } \\
1377\end{array}$ \\
\hline \multirow{2}{*}{$\begin{array}{l}\text { RURAL } \\
3944(69.97 \%)\end{array}$} & LOW RISK 2981 & PRIMIGRAVIDA & $2088(70.04 \%)$ & $674(70.03 \%)$ \\
\hline & \multirow{2}{*}{$\begin{array}{l}\text { HIGH RISK } 963 \\
\text { LOW RISK } 1279\end{array}$} & MULTGRAVDA & $893(29.96 \%)$ & $289(29.97 \%)$ \\
\hline \multirow{2}{*}{$\begin{array}{l}\text { URBAN } \\
1693(30.03 \%)\end{array}$} & & PRIMIGRAVIDA & $879(70.10 \%)$ & $292(70.58 \%)$ \\
\hline & HIGH RISK 414 & MULTIGRAVIDA & $382(29.90 \%)$ & $122(29.42 \%)$ \\
\hline
\end{tabular}

Table 3: Parity and residence of labouring women. 


\begin{tabular}{|c|c|c|c|c|c|}
\hline \multirow{6}{*}{$\begin{array}{l}\text { TOTAL NO. } \\
\text { OF } \\
\text { MATERNAL } \\
\text { CXS } \\
\text { NO \% } \\
2254 \%\end{array}$} & \multicolumn{2}{|l|}{ PARITY } & $\begin{array}{l}\text { PROLONGED } \\
\text { LABOUR }\end{array}$ & OBST LABOUR & $\begin{array}{l}\text { MODE OF } \\
\text { DELIVERY } \\
\text { V/F/LSCS }\end{array}$ \\
\hline & \multirow[t]{2}{*}{$\begin{array}{l}\text { RURAL } \\
\text { NO } \% \\
15970.76 \%\end{array}$} & $\begin{array}{l}\text { LOW } \\
\text { RISK }\end{array}$ & $\begin{array}{l}\text { NO \% } \\
122(76.98 \%)\end{array}$ & $\begin{array}{l}\text { NO \% } \\
00 \%\end{array}$ & $\begin{array}{l}\text { LSCS-38 } \\
\text { V-07 } \\
\text { F-77 }\end{array}$ \\
\hline & & $\begin{array}{l}\text { HIGH } \\
\text { RISK }\end{array}$ & $37(23.02 \%)$ & $00 \%$ & $\begin{array}{l}\text { LSCS-10 } \\
\text { F-27 }\end{array}$ \\
\hline & \multirow{2}{*}{$\begin{array}{l}\text { URBAN } \\
\text { NO } \% \\
6629.24 \%\end{array}$} & $\begin{array}{l}\text { LOW } \\
\text { RISK }\end{array}$ & $49(73.68 \%)$ & $00 \%$ & $\begin{array}{l}\text { LSCS-14 } \\
\text { F-35 }\end{array}$ \\
\hline & & $\begin{array}{l}\text { HIGH } \\
\text { RISK }\end{array}$ & $17(26.32 \%)$ & $00 \%$ & $\begin{array}{l}\text { LSCS-07 } \\
\text { F-10 }\end{array}$ \\
\hline & \multicolumn{5}{|c|}{$\begin{array}{l}\text { PROLONGED LABOUR - RURAL AS WELL AS URBAN, FACTORS DIFFERENT, } \\
\text { FORCE PS DELIVERY- MAIN STAY- PARTOGRAPHY HELPED IN DETECTING FD AT } \\
\text { RIGHT TIME AND REDUCED CSR }\end{array}$} \\
\hline
\end{tabular}

Table 4: Maternal complications.

\begin{tabular}{|c|c|c|c|c|c|}
\hline \multirow[t]{6}{*}{$\begin{array}{l}\text { FETAL \& } \\
\text { NEONATAL CX } \\
250(100 \%)\end{array}$} & \multicolumn{2}{|l|}{ PARITY } & $\begin{array}{l}\text { FETAL } \\
\text { DISTRESS/ } \\
\text { BIRTH } \\
\text { ASPHYXIA }\end{array}$ & $\begin{array}{l}\text { INTRA } \\
\text { PARTUM } \\
\text { STILL BIRTHS }\end{array}$ & $\begin{array}{l}\text { NEONATAL } \\
\text { COMPLICATIONS }\end{array}$ \\
\hline & \multirow{2}{*}{$\begin{array}{l}\text { RURAL } \\
174 \\
(69.44 \%)\end{array}$} & LOW RISK & $13(7 \%)$ & $6(4 \%)$ & $92(53 \%)$ \\
\hline & & HIGH RISK & $20(11 \%)$ & $3(2 \%)$ & $40(23 \%)$ \\
\hline & \multirow{2}{*}{$\begin{array}{l}\text { URBAN } \\
76(30.56 \%)\end{array}$} & LOW RISK & $10(13.15 \%)$ & $3(394 \%)$ & $35(46.05 \%)$ \\
\hline & & HIGH RISK & $11(14.47 \%)$ & $7(9.21 \%)$ & $10(13.15 \%)$ \\
\hline & \multicolumn{5}{|c|}{$\begin{array}{l}\text { IN ALL THE PERIOD OF STUDY AFTER USING PARTOGRAPH } 19 \text { INTRA-PARTUM } \\
\text { DEATHS OCCURRED OUT OF WHICH } 12 \text { HAD CORD AROUND THE NECK, } 1 \text { HAD } \\
\text { TRUE KNOT AND REST } 6 \text { NO OBVIOUS REASON COULD BE FOUND. }\end{array}$} \\
\hline
\end{tabular}

Table 5: Fetal and neonatal complications. 


\begin{tabular}{|l|}
\hline E-PARTOGRAPHUSED 16/11/2013 TO 07/06/2016 \\
NO OF FETAL AND NEONATAL COMPLICATIONS IN PERINATAL PERIOD-170 COMPAREDB TO \\
372 3 YEARS BEFORE IN THE SAME RERIOD WITH MARGINAL INCREASE IN DELIVERY \\
DURING THE USE OF E PARTOGRAPHY \\
\hline FRESH SB-15 (CORD AROUND THE NECK-12, TRUE KNOT-1, IN 2 UNKNOWN) \\
\hline NEONATAL DEATH-30 \\
\hline NEONATAL COMPLICATION-125
\end{tabular}

Table 6: Perinatal Morbidity and mortality.

\section{Discussion}

According to Cartmill and Thornton presentation of partogram information influences obstretic decisionmaking and according to Studd, a partogram can be used to classify normal and abnormal childbirths [5]. There are various studies that proved a positive influence of using partograms - Bosse, Massawe and Jahn claim, that partogram (which they are referring to as cervicograph) can reduce maternal and fetal morbidity and mortality [6]. According to WHO the critical function of partogram is to "give early warning that labour is likely to be prolonged" [7]. In labours where partograms were used, WHO registered a reduction of $3 \%$ in prolonged deliveries and $11 \%$ in interventions [8]. Other studies showed that the critical factor for length of labor is cervimetric progress, which is one of the most carefully observed variable in partograms. "An early warning of prolonged labour may be obtained by reference to a line representing normal cervimetric progress of primigravid labour for a given admission dilatation superimposed upon the cervicograph" [5] Research on 1000 women in Karachi proved that "by using partogram, frequency of prolonged and augmented labour, postpartum haemorrhage, ruptured uterus, puerperal sepsis and perinatal morbidity and mortality was reduced" [9]. Studies about effect of partogram on rates of Caesarean section, which is among other things related with mentioned length of labor, have an ambiguous results.
WHO registered some improvement [8], but on the other hand there are researchers that observed only minimal influence to Caesarean section - for example Seaward from University of Toronto [9]. A partogram can be used during every stage of labor, but the most frequently used partogram is the one used during the first stage of one. But according to Sizer, Evans, Bailey and Wiener the second-stage partogram can be usefull too: "A second stage partogram is a logical extension of the first stage partogram and furthers its advantages. Many factors influence progress in the second stage: the size and shape of the pelvis, which may be related to the height of the mother; birth weight; uterine action; softtissue resistance; maternal effort; and degree of flexion, caput, and molding of the fetal head. However, these factors may all be resolved into the end result of descent and rotation, which allows simplified assessment and the possibility of graphic representation" [10].

\section{References}

1. Essential Elements of Obstetrical Care at First Referral Level, $1^{\text {st }}$ Edn.. Geneva (1991).

2. Lavender T, Hart A, Smyth RMD. Effect of partogram use on outcomes for women in spontaneous labour at term. $8^{\text {th }}$ Edn. Cochrane Database of Systematic Reviews 7 (2013): CD005461.

3. Dujardin B, De Schampheleire I, Sene H, Ndiaye F. Value of the alert and action lines on 
the partogram. Lancet 339 (1992): P1336P1338.

4. RSV Cartmill, JG Thornton. Effect of presentation of partogram information on obstetric decision-making. LANCET 339 (1992): 1520-1522.

5. J. Studd. Partograms and nomograms of cervical dilatation in management of primigravid labour.. British Medical Journal 4(1973): 451-455.

6. G Bosse, S Massawe, A Jahn. The partograph in daily practice: it's quality that matters. International Journal of Gynecology \& Obstetrics 77 (2002): 243-244
7. World Health Organization. The partograph. A managerial tool for the prevention of prolonged labour.. Geneva (1989).

8. World health Organisation. World Health Organization partograph in management of labour. . THE LANCET 343 (1994): 13991404

9. Iffat Javed, Shereen Bhutta, Tabassum Shoaib. Role of partogram in preventing prolonged labour.. Journal of Pakistan Medical Association 57 (2007): 408-411.

10. SIZER. A second-stage partogram (2000).

This article is an open access article distributed under the terms and conditions of the Creative Commons Attribution (CC-BY) license 4.0 